of Red Pharaohs ascending to a nest of Mountain Bluebirds on the Griswold-Souris nestline, killing all the young, and a case of Tree Swallows meeting the same fate. In the Camp Hughes area, a small swarm of the Black Carpenters overwhelmed a nestful of half-fledged Mountain Bluebirds, and at this nest we noted the parent birds perched on a high wire, the picture of silent dejection. Clearly they had not been able to cope with the invaders.

From the smallest enemies of the Mountain Bluebird, we now turn to Man who must rate as the greatest peril of all. To point up this statement, our nestlines have suffered over 250 cases of vandalism during the past 12 years of operation; nestboxes have been destroyed by shooting, or have been knocked down, smashed, or simply stolen. In addition, many more have been robbed - in one instance 10 consecutive nests had all the eggs taken on the same day. The parent birds are often shot, or one of a breeding pair is shot, resulting in the abandonment of the nest (see above). Some years ago our junior birders set out eight nestboxes on a fence enclosing a horse run. The first year of operation found no less than seven pairs of bluebirds using the nests, so the lads named this spot "Bluebird Square." All went well with this nestline till the early summer of 1970 , when we found "Bluebird Square" completely shattered, with every nestbox smashed or robbed, and the corpses of two Mountain and one Eastern Bluebirds strewn about.
Not a single successful bluebird nesting was recorded for this spot in 1970 , so completely had the birds been driven out.

Some form of man-caused pollution appears to have reached our breeding populations of Mountain Bluebirds by mid-June, 1970 (Lane and Bauman, 1970 ), and, in the absence of any certain proof, we can only suspect that the deaths of between 200 and 350 young bluebirds were caused by some type of food poisoning, probably of insecticide origin.

Despite all the foregoing, it is a matter for great rejoicing that the exquisite Mountain Bluebird continues to multiply on the Canadian prairies, as does his lovely cousin, the Eastern Bluebird. Both species have shown that, given the necessary nestholes and as much protection as possible, they can and will thrive in our midst, imparting joy and beauty to the eye and ear of the beholder.

\section{LITERATURE CITED}

Bent, A. C. 1949. Life histories of North American thrushes, kinglets, and their allies. Smithsonian Institution. U.S. Nat'l. Mus., Bull. 196.

Lane, J. and V. Bauman. 1970. Tenth annual report of the Brandon Juniors' nesting project. Blue Jay, 28:175.

Miller, W. 1968. Predation of bluebirds by an Eastern Chipmunk. Biue Jay, 26:145.

Power, H. W. 1966. Biology of the Mountain Bluebird in Montana. Condor, 68:366-367.

Randall, D., and J. Lane. 1969. Ninth annual report of the Brandon Juniors' nestbox project. Blue Jay, $27: 215$.

Swenson, J. E. 1968. The Deer Mouse as a nest competition and possible predator on the Mountain Bluebird. Blue Jay, $26: 214$.

\title{
OBSERVATIONS OF TURKEYS IN BRITISH COLUMBIA
}

\section{by William J. Merilees, Selkirk College, Castlegar, B.C.}

The Turkey, Meleagris gallopavo, was once a native resident species in eastern Canada, but no longer occurs there except where recently introduced (Godfrey, 1966).

In recent years Turkeys have been introduced in the states of Washington and Montana, some of these releases being close to British Columbia. Since then some of these birds have crossed the International Boundary into southern British Columbia (see map). Turkeys have been reported from two locations: the Pend Oreille Valley southeast of Trail in the West Kootenay, and near Newgate, south of Elko in 
the East Kootenay. Both these areas are within 50 miles of the release areas 10 miles south of Kettle Falls, Washington ( S. Guenther, pers. comm., September 22, 1969) and near Eureka, Montana (R. J. Greene, pers. comm., May 7, 1970).

In Washington, Turkeys have moved up to 50 miles in four years. From the original release south of Kettle Falls, the birds have spread northeast; now there is a good population near Marcus, 25 miles from the Canadian Border, and broods were known to have been raised near Northport, six miles from the Border. In 1967 several reports were received of sightings in B.C.: two from Trail, one from Nelson, and several from the Pend Oreille Valley (S. Guenther, pers. comm.). In Montana, released birds spread 20 to 30 miles from the release site, some even being found up to $5000^{\prime}$ elevation. Sightings were also reported from B.C. (L. Netzloff, pers. comm., January 28, 1970). From the releases near Eureka, birds could easily have reached B.C. as stringers of yellow pine and river bottom land run into Canada ( $R$. J. Greene, pers. comm.).

I have visited the Pend Oreille Valley on numerous occasions but I have not been able to locate any Turkeys, though I have found their droppings. In my enquiries I have located many people who have seen Turkeys in southern B.C. and from these people the following notes have been taken: Karoly Gorog, Secretary - Treasurer, Trail Wildlife Association, Trail, B.C. stated (pers. comm., May 7, 1970) : "I saw the turkeys in May 1967, 15-16 miles up the road on the Pend Oreille River above the Waneta Bridge. There were four adult full grown birds. I watched them for about 5-6 minutes then they wandered away."; Gordon T. Earl, rancher, Newgate, B.C. stated (pers. comm., December 14, 1969) : "It would be two years now since we have seen any on our place. They were very shy, really swift afoot; colouring very similar to the tame, but not as large."; Peter Berukoff, Sr., rancher, Pend Oreille Valley, stated (pers. comm., December 8, 1970) : "Between Septem- ber and November, 1967, I saw flocks of up to 50 birds on a number of occasions between Nine and Twelve Mile Creeks." (Flocks at this time (Jonas, 1966) would be composed of both adult and juvenile birds, indicating breeding had taken place in the previous months.) ; Russ Fletcher, hunter, Nelson, B.C. (pers. comm., February 18, 1970): "I saw a wild turkey around the middle of November, 1969, in the Salmo Valley near the Black Bluffs." (Nine miles south of Salmo.)

The Fish and Wildlife Branch of the British Columbia Government has made no releases of Turkeys in the Province, and residents living in the Pend Oreille Valley have not raised domestic Turkeys, the valley being used solely as range land for cattle. Turkeys have also been shot in the Pend Oreille Valley on a number of occasions, particularly in the fall of 1967, but owing largely to fear of prosecution under the game laws no proof is available. From this information there is little doubt that a small number of Turkeys have crossed into Canada. Some appear to be resident and in 1967 at least have been thought to breed.

The question of whether the Turkey can withstand severe winters would appear to be an important factor in maintaining a small population in British Columbia. In Montana they have withstood temperatures of 53 degrees below zero (Fahrenheit) and two to three week periods of subzero weather with four feet of snow (L. Netzloff, pers. comm.). The subspecies of Turkey involved in these introductions, Meleagris gallopavo merriami, has had particular success in ponderosa pine forests, pine seeds being their preferred item of diet (Jonas, 1966). S. Guenther (pers. comm.) considers the area around Trail, B.C., including the Pend Oreille Valley, fairly good turkey habitat which, though it would not support a large population, would always support a few birds.

In British Columbia, ponderosa pine forests cover a considerable portion of the southern interior (Brayshaw, 
